\title{
Photodynamic ability of silver nanoparticles in inducing cytotoxic effects in breast and lung cancer cell lines
}

This article was published in the following Dove Press journal:

International Journal of Nanomedicine

12 August 2014

Number of times this article has been viewed

\author{
Ivan Mfouo-Tynga' \\ Ahmed El-Hussein ${ }^{1,2}$ \\ Mohamed Abdel-Harith ${ }^{2}$ \\ Heidi Abrahamse' \\ 'Laser Research Centre, Faculty of \\ Health Sciences, University \\ of Johannesburg, Doornfontein, \\ South Africa; ${ }^{2}$ National Institute \\ of Laser Enhanced Sciences, \\ University of Cairo, Giza, Egypt
}

\begin{abstract}
Cancer is still a major health problem, and the use of nanomedicine for cancer treatment has become a new focus area for research. The multifunctional effects of silver nanoparticles (AgNPs) have made these nanostructures potent compounds for biomedical applications. AgNPs were characterized by transmission electron microscopy for their size, shape, and cellular localization; ultraviolet-visible spectroscopy for absorption properties; and their zeta potential for determining their surface charge. Cytotoxicity effects on both MCF-7 breast and A549 lung cancer cell lines were assessed using inverted light microscopy, Trypan blue exclusion assay, adenosine triphosphate luminescence, and lactate dehydrogenase membrane integrity assays. The cell death mechanism was determined by Annexin V and propidium iodide flow cytometric analysis. The results showed that AgNPs used during the present study were found to be of spherical shape, with $-0.0261 \mathrm{mV}$ surface net charges, with an average size of $27 \mathrm{~nm}$, and they were positively identified in both cell lines. Irradiated AgNPs promoted decreased viability and proliferation, increased cytotoxicity, and induced programmed cell death through apoptosis. AgNPs exhibited photodynamic activity in both cancer cell lines, but MCF-7 cells showed enhanced cytotoxic effects over the A549 cells. The novelty related to the study presented is twofold: while the maximum absorbance of most AgNPs lies in the wavelength region of 370-450 nm, the AgNPs produced and used in this research have a peak absorption at $631 \mathrm{~nm}$ that is of great significance, since this wavelength lies within the biological therapeutic window. This work clearly demonstrates that our AgNPs activated at $635 \mathrm{~nm}$ contribute significantly to the cytotoxicity induced in cancer cells, but more so in breast cancer cells (MCF-7) than in lung cancer cells (A549).
\end{abstract}

Keywords: nanotechnology, silver nanoparticles, cell damage, breast cancer, lung cancer

\section{Introduction}

Cancer is a form of uncontrolled cell proliferation that has become a major health-threatening condition. This condition kills more people than tuberculosis, human immunodeficiency virus/acquired immunodeficiency syndrome, and malaria combined in developing countries, and it is the second leading cause of death after heart-related deaths. ${ }^{1-3}$ The progression of cancer is the result of impaired repair and control mechanisms within normal cells caused by both exogenous as well as endogenous effectors. The risk of developing cancer is age-dependent, with the majority of the population diagnosed at ages over 45 years worldwide ${ }^{4-9}$ Cancer of the breast glands is the most prevailing and has become the most common cause of death in women worldwide. ${ }^{3}$ Lung cancer is a highly metastatic disease, and it ranks as the second most frequently occurring cancer in both males and females. ${ }^{3,8}$ Most cancers are diagnosed at the later stages, which renders surgical procedures inappropriate due to high fatality rates. Surgical resection, chemotherapy, and radiation therapy
Laser Research Centre, Faculty of Health Sciences, University of Johannesburg, PO Box I70II, Doornfontein, 2028, South Africa

Tel +27 I I 5596406

$\mathrm{Fax}+27$ II 5596558

Email habrahamse@uj.ac.za 
are standard practices, but the ability of cancerous cells to develop multidrug resistance and a high degree of toxicity to the tissues surrounding the adjacent neoplastic ones are the major obstacles. ${ }^{10}$ Thus, novel means of managing cancer are constantly being investigated. ${ }^{10-12}$

Nanotechnology is an interesting interdisciplinary field of research involving chemistry, engineering, and biomedicine. Depending on the nature of a distinct particle, nanoparticles can be used for drug delivery, cancer diagnosis, and therapy. ${ }^{13}$ In addition to their recognized role in drug delivery, nanomaterials are employed as diagnostic sensors for the early identification of cancer, and at concentrations as low as 3-5 cancer cells in any given sample. ${ }^{14}$ This represents a tremendous benefit in the fight against cancer, as early detection remains a foremost challenge. ${ }^{14-16}$ Nanostructures are essential for the diagnosis of various conditions, and nanocrystalline silver was one of the initial nanomaterials used for the detection and treatment of microbial infections. ${ }^{17-20}$ The possibility of being able to tailor nanostructures in order to achieve specific goals continues to lead to improved means of addressing current issues, including absorption of therapeutic compounds, improved photoactivation and photodiagnosis. ${ }^{21}$

Nanoparticles are 10-10,000 times smaller than cellular organelles, and their affinity to biomolecules on the surface and inside the cells is beneficial for diagnostic and therapeutic applications. They have high surface areas, good biocompatibility, as well as good surface functionalization. ${ }^{22,23}$ Metal atoms are used for various applications according to the discipline and objectives of each application. Silver nanoparticles (AgNPs) have attracted interest due to their distinctive features and applications in ink-jet printing, cosmetics, domestic appliances and, most importantly, their antimicrobial effects. ${ }^{24,25}$ This type of nanoparticle also possesses antitumor effects and can affect the neurons and undifferentiated cells. ${ }^{24-26}$ AgNPs induce cell damage in a dose- and size-dependent manner; a higher dose and a smaller size lead to increased cytotoxic effects. ${ }^{27}$ Radiation has been shown to enhance the antitumor effects of coated nanoparticles in both colorectal adenocarcinoma and breast cancer cells. ${ }^{27,28}$ The current study aimed to investigate the combined effect of AgNPs and laser irradiation in inducing cell damage in both breast (MCF-7) and lung (A549) cancer cell lines.

\section{Materials and methods}

Breast (MCF-7) and lung (A549) cancer cell lines originated from the American Type Cell Culture (ATCC; Manassas, VA, USA) (ATCC HTB-22 and ATCC HTB-53, respectively). Cell culture growth media were manufactured by Gibco ${ }^{\circledR}$ (Thermo Fisher Scientific, Waltham, MA, USA). Cellular assays
Trypan blue exclusion and Annexin V propidium iodide (PI) were supplied by Sigma-Aldrich Co. (St Louis, MO, USA). The CellTiter-Glo ${ }^{\circledR}$ Luminescent Cell Viability Assay and CytoTox $96^{\circledR}$ Assay were purchased from Promega (Promega Corporation, Madison, WI, USA). The AgNPs were synthesized and obtained from the Institute of Photonic Technology in Jena, Germany. The AgNPs used were synthesized and characterized, as described by both Knauer et $\mathrm{al}^{29}$ and Kelly et al. ${ }^{30}$ The stock solution of AgNPs had a concentration of $80.884 \mathrm{mg} / \mathrm{mL}$. The ultraviolet-visible (UV-vis) absorption spectrum was recorded on a 2450 spectrophotometer (Shimadzu Scientific Instruments, Kyoto, Japan), which was equipped with a $1 \mathrm{~cm}$ matched quartz cell that was attached to the computer. All laser irradiation was performed using a $635 \mathrm{~nm}$ diode laser (supplied by the National Laser Centre of South Africa, Pretoria, South Africa) at a fluence rate of $10.288 \mathrm{~mW} \cdot \mathrm{cm}^{2}$, and samples were irradiated for 16 minutes and 11 seconds, 24 minutes and 17 seconds, and 32 minutes and 23 seconds to deliver light doses of $10 \mathrm{~J} / \mathrm{cm}^{2}$, $15 \mathrm{~J} / \mathrm{cm}^{2}$, and $20 \mathrm{~J} / \mathrm{cm}^{2}$, respectively (Table 1). The size, shape, and cellular uptake of AgNPs were determined by transmission electron microscopy (TEM). The zeta potential of AgNPs was measured on a Malvern Zetasizer Nano ZS (Malvern Instruments, Malvern, UK) at $25^{\circ} \mathrm{C}$ and at a $12^{\circ}$ angle. Measurements were performed in triplicate. Cellular microscopy was determined by inverted light microscopy (CKX41; Olympus Corporation, Tokyo, Japan), the measurements of the cellular assays were performed on a Victor3 Multilabel Plate Reader (PerkinElmer Inc., Waltham, MA, USA), and the flow cytometry assay was performed on the BD FACSAria ${ }^{\mathrm{TM}}$ (642226; BD Biosciences, San Jose, Ca, USA).

\section{Cell culture and cell treatment}

Breast cancer cells (MCF-7 cell line) were cultured in Dulbecco's Modified Eagle's Medium, and lung cancer cells (A549 cell line) were cultured in Roswell Park Memorial

Table I Parameters of the lasers used in this study

\begin{tabular}{ll}
\hline Parameters & Diode laser \\
\hline Manufacturer & Oriel Corporation \\
Wavelength & $636 \mathrm{~nm}$ \\
Wave emission & Continuous \\
Spot size & $9.1 \mathrm{~cm}^{2}$ \\
Output power & $88 \mathrm{~mW}$ \\
Power density & $10.288 \mathrm{~mW} / \mathrm{cm}^{2}$ \\
Fluences & $10 \mathrm{~J} / \mathrm{cm}^{2}$ \\
& $15 \mathrm{~J} / \mathrm{cm}^{2}$ \\
& $20 \mathrm{~J} / \mathrm{cm}^{2}$ \\
Irradiation times & $16 \mathrm{minutes}, 11$ seconds \\
& 24 minutes, I7 seconds \\
& 32 minutes, 23 seconds \\
\hline
\end{tabular}


Institute medium; both media were supplemented with 10\% fetal bovine serum (Gibco ${ }^{\circledR} 306.00301$; Thermo Fisher Scientific), 1\% penicillin/streptomycin/fungizone (GE Healthcare Bio-Sciences Corp., Piscataway, NJ, USA) in a $85 \%$ humidified atmosphere at $37^{\circ} \mathrm{C}$ and $5 \% \mathrm{CO}_{2}$. When confluent, cells were washed twice with Hank's balanced salt solution (HBSS; Thermo Fisher Scientific) and trypsinized using $1 \mathrm{~mL} / 25 \mathrm{~cm}^{2}$ of TrypLE ${ }^{\mathrm{TM}}$ Express (Gibco ${ }^{\circledR}$; Thermo Fisher Scientific). A final concentration of $3 \times 10^{5}$ was used to seed cells in $3.3 \mathrm{~cm}$ diameter culture dishes and they were incubated for 4 hours to allow the cells to attach. Thereafter, cells were treated with AgNPs by adding $120 \mu \mathrm{L}$ of the stock solution in $3 \mathrm{~mL}$ to give a concentration of $3.23 \mathrm{mg} / \mathrm{mL}$, and they were incubated overnight. Then, laser irradiations were performed to deliver a dosage of $10 \mathrm{~J} / \mathrm{cm}^{2}, 15 \mathrm{~J} / \mathrm{cm}^{2}$, and $20 \mathrm{~J} / \mathrm{cm}^{2}$. To avoid light interference, cells were irradiated in the dark without the culture dish lid at room temperature, and the laser spot size covered the entire area of the culture dish $\left(9.1 \mathrm{~cm}^{2}\right)$ through a fiber optic set at $8 \mathrm{~cm}$ above the cell monolayer. Cell cultures were divided into four study groups: group 1 were the untreated cells that contained no AgNPs and they were not irradiated; group 2 was not irradiated but contained AgNPs (3.23 mg/mL, AgNPs); group 3 was irradiated for $32 \mathrm{~min}$ utes and 23 seconds, but it contained no AgNPs $\left(20 \mathrm{~J} / \mathrm{cm}^{2}\right)$; and group 4 received AgNPs and was irradiated at different dosages $\left(10 \mathrm{~J} / \mathrm{cm}^{2}, 15 \mathrm{~J} / \mathrm{cm}^{2}\right.$, and $\left.20 \mathrm{~J} / \mathrm{cm}^{2}\right)$.

\section{Transmission electron microscopy}

Cells were incubated for 24 hours with $3.23 \mathrm{mg} / \mathrm{mL}$ of AgNPs. After incubation, cells were washed, trypsinized, and centrifuged at 2,200 rpm for 5 minutes. Cell pellets were treated with $1 \mathrm{~mL}$ of $2.5 \%$ glutaraldehyde in $0.075 \mathrm{M}$ sodium phosphate buffer and incubated for 2 hours. Cell samples were rinsed three times for 15 minutes with $0.0075 \mathrm{M}$ sodium phosphate buffer. Cell samples were fixed in 1\% osmium tetraoxide for 2 hours and rinsed three times for 15 minutes with distilled water. Then, cell samples were sequentially dehydrated for 15 minutes with 30\%, 50\%, 70\%, 90\% and three times with $100 \%$ ethanol. Thereafter, the samples were infiltrated, embedded, and polymerized for TEM analysis.

\section{Evaluation of the cytotoxic effects of AgNPs Cellular morphology: inverted light microscopy}

After 24 hours of treatment, the morphology of different cell groups and changes in cell structure were examined using an inverted microscope (CKX41) and compared to the untreated control group. Images of cellular morphology were taken using the SC30 camera (Olympus Corporation). Each image was compared to that of the untreated cells (group 1). Indicators such as debris, cellular fragments, and the number of free-floating cells were taken into consideration to determine the degree of change in cell viability and increased mortality of the cells.

\section{Cell viability:Trypan blue exclusion assay}

A Trypan blue exclusion assay was performed to determine the cell count and percentage viability after treatment. Ten microliters of cell suspension was added to $90 \mu \mathrm{L}$ of $0.4 \%$ Trypan blue in HBSS (1:10 dilution) and carefully mixed. The Trypan blue cell suspension mixtures were allowed to stand for 3 minutes before a small volume $(10 \mu \mathrm{L})$ was transferred to both counting chambers on either side of a Bright-Line ${ }^{\mathrm{TM}}$ hemocytometer (Sigma-Aldrich Co.) by placing a pipette tip at the edge of the coverslip and allowing each chamber to fill by capillary action. The hemocytometer was viewed under a microscope (CKX41), and the total number of cells (intact and damaged) in both chambers was counted. The total number of cells was determined by multiplying the average number of cells per square by $10^{5}$ (dilution factor $\times 10^{4}$ ). The viability percentage was obtained by multiplying the fraction of the number of viable cells over the total number of cells by 100 .

\section{Cell proliferation:ATP luminescence}

Adenosine triphosphate (ATP) luminescence was evaluated after treatment to assess cell proliferation using the CellTiter$\mathrm{Glo}^{\circledR}$ Luminescent cell proliferation assay. The ATP assay exploits the ability of luciferase to produce a luminescent signal and inhibits endogenous ATP release during cell lysis. Fifty microliters of the ATP CellTiter-Glo ${ }^{\circledR}$ reagent was added to an equivalent volume of cell suspension for each different treatment in an opaque-walled 96-well plate. The plate was mixed for 2 minutes to induce lysis and was incubated for 10 minutes at room temperature in the dark. The application led to the production of a luminescent signal that was measured using a Victor3 Multilabel Reader in relative light units (RLU). A background control well containing $50 \mu \mathrm{L}$ of media was included, and the RLU value obtained from the background control well was deducted from all the RLU values of the other wells.

\section{Cytotoxicity: LDH membrane integrity}

Cytotoxicity was assessed by measuring the amount of lactate dehydrogenase (LDH) released from the cytosol due to membrane damage using the CytoTox $96{ }^{\circledR}$ nonradioactive cytotoxicity assay. In the nonradioactive colorimetric assay, LDH reduces nicotinamide adenine dinucleotide (NAD) to NADH 
then reacts with a specific probe to produce a tetrazolium salt (in the reconstituted reagent, which is in an oxidized form) into a quantifiable red formazan product (reduced form). The product of this enzymatic reaction is proportional to the number of cells that have been damaged. ${ }^{31}$ Fifty microliters of reconstituted reagent were added to an equal volume of culture media for each group in a 96-well plate and incubated in the dark at room temperature for 30 minutes. The colorimetric compound was measured spectrophotometrically at 490 nm using a Victor3 Multilabel Reader.

\section{Cell death: flow cytometric analysis}

The cell death events and types of cell populations (normal or dying cells) were studied after treatment. The assay uses Annexin V-fluorescein isothiocyanate (FITC) and PI to identify phosphatidyl serine sites on the membrane of apoptotic cells, as well as sites of membrane damage in necrotic cells, respectively. Therefore, this assay measured two parameters: whether the cells have affinity first to Annexin V-FITC and secondly whether the cells have affinity to PI. The assay gave an overview of the cell population based on their respective affinities: apoptotic cells (Annexin V-FITC positive and PI negative or positive for both Annexin V-FITC and PI), necrotic cells (Annexin V-FITC negative and PI positive) and viable cells (Annexin V-FITC negative and PI negative). After treatment and incubation, all cells were trypsinized and washed with HBSS. Cells were resuspended in $1 \mathrm{X}$ binding buffer at a concentration of $1 \times 10^{6}$ cells $/ \mathrm{mL}$, and $100 \mu \mathrm{L}$ of the cell suspension was transferred into flow cytometry tubes. Five microliters each of the Annexin V-FITC and PI reagents were added, and the tubes were thoroughly mixed and incubated for 10 minutes at room temperature in the dark. Within 1 hour, flow cytometric analysis was performed on the BD FACSAria. Annexin V-FITC was detected as green fluorescence and PI as red.

\section{Statistics}

A breast cancer cell line was used with subcultures between 15-18 times and the lung at 17-20 times. Each set of experiments was repeated four times (number $=4$ ), while each assay was done in duplicate; the results were averaged. Untreated cells were included throughout the course of the study, and all treated samples were compared to these cells by means of one-way analysis of variance to determine the statistical difference. Statistical analysis was done using OriginPro 8 (OriginLab Corporation, Northampton, MA, USA) and the mean, standard deviation, and standard error were obtained. The statistical significances between untreated MCF-7 and
A549 cells and treated cells are shown in Figures 4, 5 and 6 as $P$-values.

\section{Results and discussion}

AgNPs were characterized using TEM, UV-vis spectroscopy, and zeta potential. TEM was used to determine the size, shape, and cellular uptake of AgNPs. Figure 1 shows that AgNPs were sphere-shaped with an average size of $27 \mathrm{~nm}$, and that the AgNPs were successfully taken up by both MCF-7 and A549 cancer cells. Although the contrast obtained in the images was not optimal, which may be the result of the fixation method used and/or the incubation period, it successfully proved that the particles were absorbed and located within the cancer cells. The chemical fixation and/or the incubation period may have affected the quality of the images of the nanoparticles. We will aim to apply cryofixation for better resolution in further work. These spherical nanoparticles were relatively smaller than the spherical AgNPs, the sizes were between 22.30 to $37.04 \mathrm{~nm}$ as seen in Figure 1C, which were found to have antiapoptotic activities in lung cancer cells. ${ }^{32}$ Such small nanostructures are highly diffusible; they can easily pass through cell membranes and have been proven to enhance therapeutic mechanisms. ${ }^{33}$ The absorption property is an important distinctive feature of nanoparticles, and UV-vis spectra was performed to determine the absorption property of AgNPs. From Figure 2, the absorption peak was found to be at $631 \mathrm{~nm}$. This absorption band lies in the therapeutic window, where visible light can be deeply absorbed with nondestructive effects on biological tissues. That makes AgNPs very convenient sensitizers for photothermal applications. The zeta potential to determine the surface charge of nanosilver compounds was found to be slightly negatively charged $(-0.00261 \mathrm{mV})$.

An evaluation of the cytotoxic effects of AgNPs was performed. After treatment, AgNPs were identified in the cells, the cellular morphologies of both breast and lung cancer cells were assessed, and the morphological features of cells treated with laser irradiation alone or AgNPs alone were found to be similar to the untreated control cells in both cell lines. AgNPs and laser irradiation together induced an increase in the number of free-floating cells (Figure 3). Similar effects were also reported after laser-activated zinc-phthalocyanine led to cytodamage, cell detachment, and death in both breast and lung cancer cells. ${ }^{34,35}$ Quantitative assays were performed to establish the degree of cytodamage. Table 2 shows that the individual effects of either the laser or AgNPs did not trigger a major decrease in the viability percentage. However, the viability percentage significantly dropped in all photodynamic therapy (PDT)-treated cells. Decreased viability of cancer 

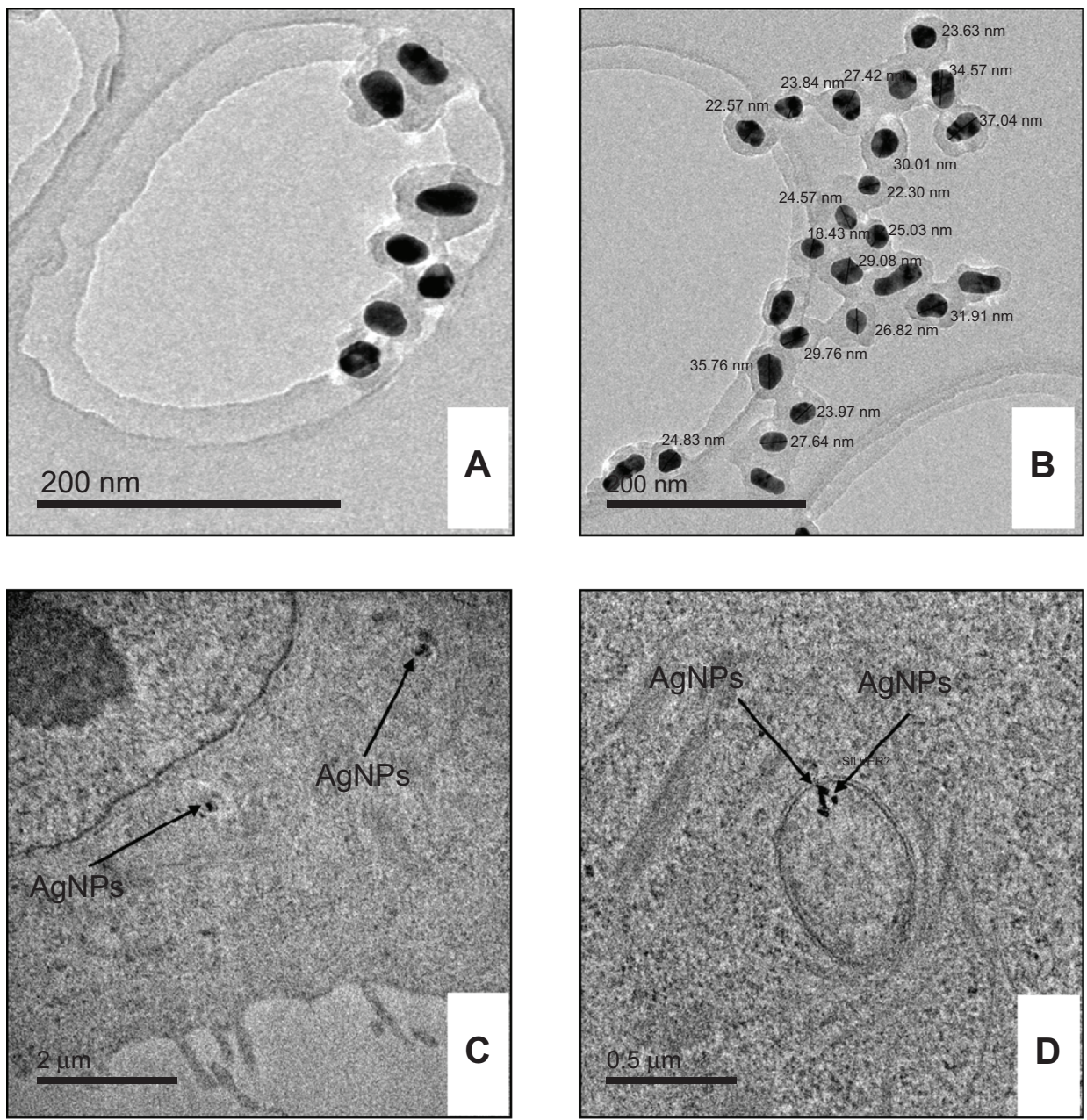

Figure I Transmission electron microscopy of the AgNPs.

Notes: (A) AgNPs have a spherical shape (B) with an average size of $27 \mathrm{~nm}$. AgNPs were taken up by both (C) MFC-7 breast and (D) A549 lung cancer cells. Abbreviation: AgNPs, silver nanoparticles.

cells after treatment with AgNPs was also seen in another in vitro study, ${ }^{36}$ where the effects were screened and showed decreased viability in a dose-dependent manner. The same study concluded that AgNPs showed good antitumor effects and were better than other metal nanostructures. ${ }^{36}$ Decreased

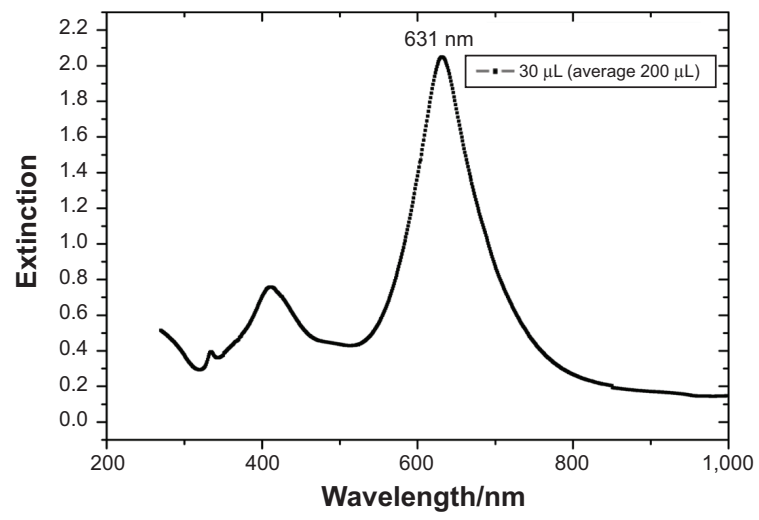

Figure 2 The absorption spectrum of AgNPs in phosphate buffered saline. Note: AgNPs have a peak absorption at $631 \mathrm{~nm}$.

Abbreviation: AgNPs, silver nanoparticles. viability and the inhibition of proliferation in A549 cancer cells were seen when the effects of AgNPs that were $30 \mathrm{~nm}$ in size were tested. ${ }^{32}$

In the current study, the cell proliferation in both cell lines did not decrease significantly when laser irradiation alone and AgNPs alone were applied; however, when both laser and AgNPs were combined in PDT, their effects led to a significant decrease in proliferation in both breast and lung cancer cells (Figures 4A and 4B, respectively). Taken independently, AgNPs were unable to display increasing antiproliferating effects, but after irradiation, AgNPs showed improved antitumor activities. A previous study on HeLa cancer cells ${ }^{37}$ showed that the association of AgNPs with other factors, such as the low concentration of an antitumor drug, led to decreased cell proliferation; the fact that the silver nanoparticles were localized in the cancer cells indicated that they play a critical role in cancer therapy. ${ }^{37}$ With sizes ranging from 20-50 nm, nonirradiated AgNPs cause 5\%-10\% decreased viability, but at the same concentration, irradiated 

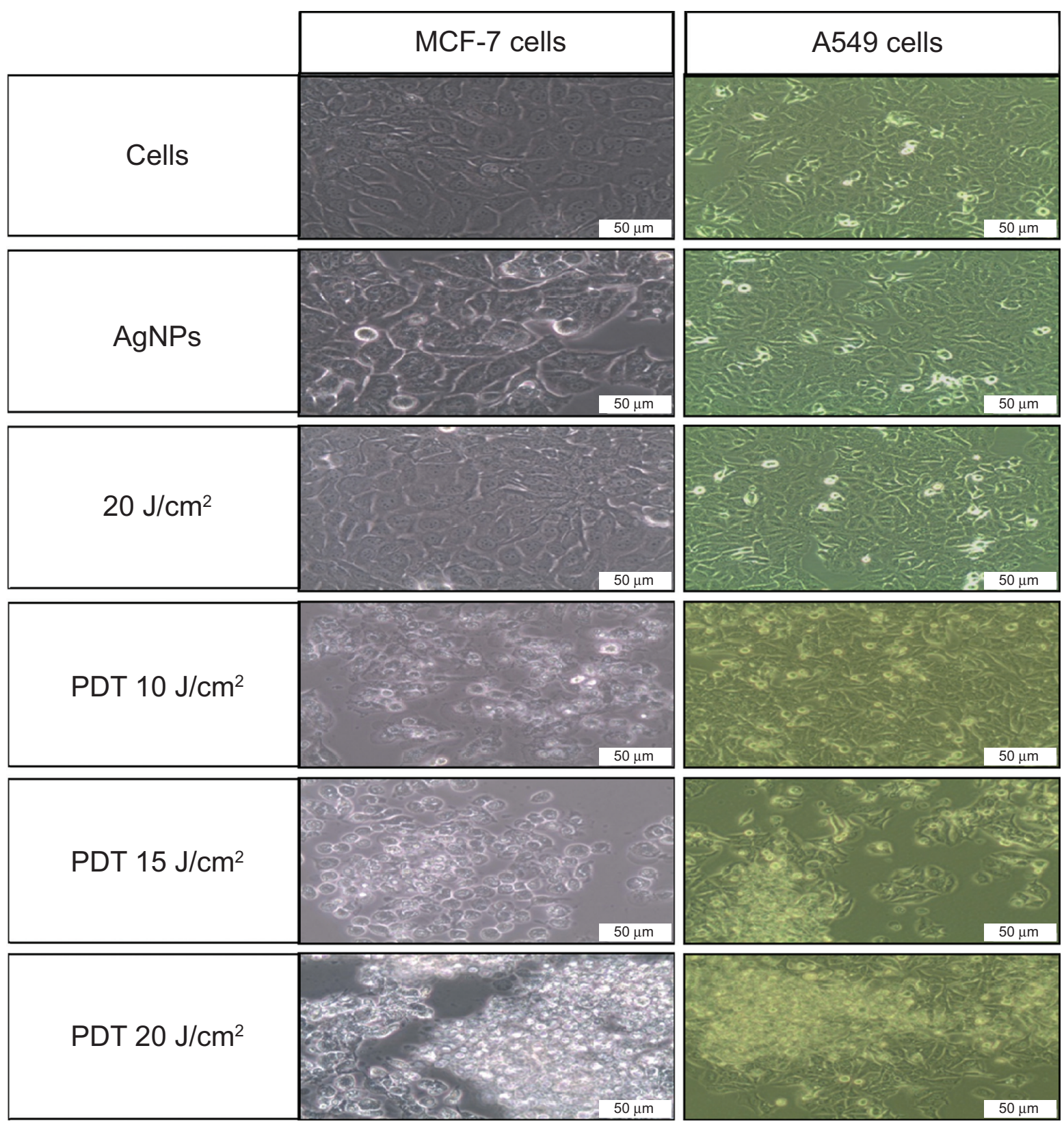

Figure 3 Cellular morphology after the treatment of MCF-7 breast and A549 lung cancer cells.

Notes: Cells treated with either $3.23 \mathrm{mg} / \mathrm{mL}$ of AgNPs (AgNPs) or $20 \mathrm{~J} / \mathrm{cm}^{2}$ laser irradiation $\left(20 \mathrm{~J} / \mathrm{cm}^{2}\right)$ did not morphologically differ from the untreated cells (cells) in both cell lines. After treatment with both AgNPs and laser irradiation, PDT-treated cells appeared to be different, with an increased number of free-floating cells; this was more pronounced in MCF-7 cells.

Abbreviations: AgNPs, silver nanoparticles; PDT, photodynamic therapy.

AgNPs led to the enhanced laser-induced death of glioma cells. That enhancement of cytodamage was a function of the irradiation and $20 \mathrm{~nm}$ sized nanoparticles, which performed better than the $50 \mathrm{~nm}$ ones. ${ }^{38}$

The present work shows that laser irradiation by itself, as well as AgNPs alone, led to insignificant increases in the levels of LDH, but more cytodamage and substantial LDH release were noted in both the PDT-treated breast and lung cancer cells (Figures 5A and 5B, respectively). Such intense membrane and cell damage might be due to the release of
$\mathrm{Ag}^{+}$cations from the average-sized $27 \mathrm{~nm}$ AgNPs upon laser irradition. These cations are effectors of cell death, and they are able to capture electrons by acting as oxidative entities, reducing cellular ATP contents, and enhancing the formation of reactive oxygen species. ${ }^{39}$ Smaller and irradiated nanoparticles release more silver ions $\left(\mathrm{Ag}^{+}\right)$than do larger nanostructures. Figure 6 shows the significant increased cell viability and proliferation and decreased cytotoxicity $(P<0.005)$ for PDT $=$ treated MCF-7 cells with an irradiation fluence of $20 \mathrm{~J} / \mathrm{cm}^{2}$ when compared to the A549 cells. This 
Table 2 Trypan blue cellular viability of MCF-7 and A549 cells

\begin{tabular}{lll}
\hline Experimental groups & \multicolumn{2}{l}{ Cell viability (\%) } \\
\cline { 2 - 3 } & MCF-7 & A549 \\
\hline Cells & 91.83 & 94.66 \\
AgNPs & 92.16 & 92.66 \\
$20 \mathrm{~J} / \mathrm{cm}^{2}$ & 89.66 & 93.50 \\
PDT $10 \mathrm{~J} / \mathrm{cm}^{2}$ & $77.14 * * *$ & $84.88^{*}$ \\
PDT $15 \mathrm{~J} / \mathrm{cm}^{2}$ & $76.37 * * *$ & $83.83^{* *}$ \\
PDT $20 \mathrm{~J} / \mathrm{cm}^{2}$ & $73.42 * * *$ & $81.66 * *$ \\
\hline
\end{tabular}

Notes: Both cells that received AgNPs of $3.23 \mathrm{mg} / \mathrm{mL}$ concentration and those that were laser irradiated $\left(20 \mathrm{~J} / \mathrm{cm}^{2}\right)$ showed little change to the viability percentage when compared to untreated cells (cells). Significant decreases in viability percentage were seen in all PDT-treated cells and were indicated as $*(P<0.005)$, $* *(P<0.002)$, and $* * *(P<0.00 \mathrm{I})$ when compared to the untreated controls (cells) of the respective cell line.

Abbreviations: AgNPs, silver nanoparticles; PDT, photodynamic therapy

finding could have been due to the ability of MCF-7 cells to inhibit the activity of dehydrogenases; enzymes that catalyze reactions involving the oxidation of substrates by a reduction coupled with electron transfers. This triggers the induction of apoptosis in these cancer cells and it is associated with accumulation of ubiquitinated proteins and three known proteasome target proteins, the cyclin-dependent kinase

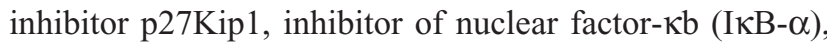
and the pro-apoptotic protein Bax. ${ }^{40}$ Cancer cells are capable of enhancing the rate of energy production, and dehydrogenases catalyze the reactions that produce high-energy compounds such as NADH and flavin adenine dinucleotide (FAD), both of which are used for energy production through oxidative phosphorylation. ${ }^{41}$ Work done by Franco-Molina et a ${ }^{42}$ proved that MCF- 7 cells treated with colloidal AgNPs significantly reduced the level of activity of dehydrogenases, which can then lead to the induction of apoptotic events, a decreased NADH/NAD ${ }^{+}$ratio, and mitochondrial membrane potential. The mitochondrial membrane potential is followed by mitochondrial inner membrane permeabilization, depolarization and swelling, cytochrome c release, and apoptotic death. The mitochondrial reactive oxygen species (ROS) are critical in initiating mitochondrial inner membrane permeabilization, which leads to mitochondrial swelling, cytochrome $\mathrm{c}$ release to the cytosol, and apoptotic death during PDT. The eventual MCF-7 cell inhibition of dehydrogenases and energy production, coupled with AgNPs, induced the generation of reactive oxygen and/or nitrogen species, which led to the increased toxicity and sensitivity of MCF-7 to AgNP-mediated photodamage.

For a greater understanding of the cytodamage mechanisms seen in both cell lines, flow cytometric analysis was performed. Both Annexin V-FITC for apoptosis and PI for necrosis were used to stain the treated and damaged cells. Flow cytometric analysis revealed that the majority of the cells in the untreated control and AgNP-treated samples were viable, as they stained negative for both Annexin V-FITC and PI (Table 3). However, when compared to the same population of untreated control cells, a decrease in the cell normal population and increase in the early apoptotic cell population (positive for Annexin V-FITC) and late apoptotic cell population (positive for both Annexin V-FITC and PI) were noted with AgNP-mediated PDT cells, and the population of normal or viable cells significantly decreased. Changes in necrotic cell populations (positive for PI) were noted with the breast and lung cancer
A

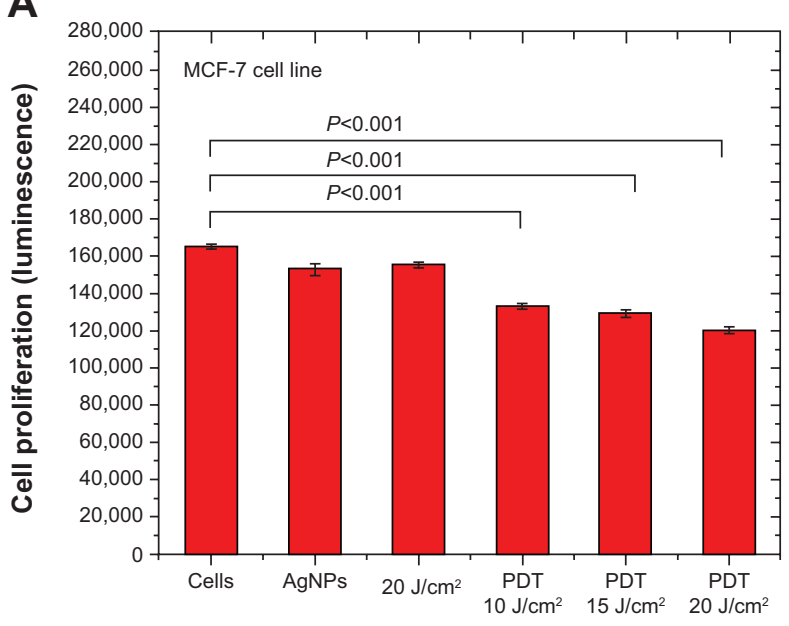

B

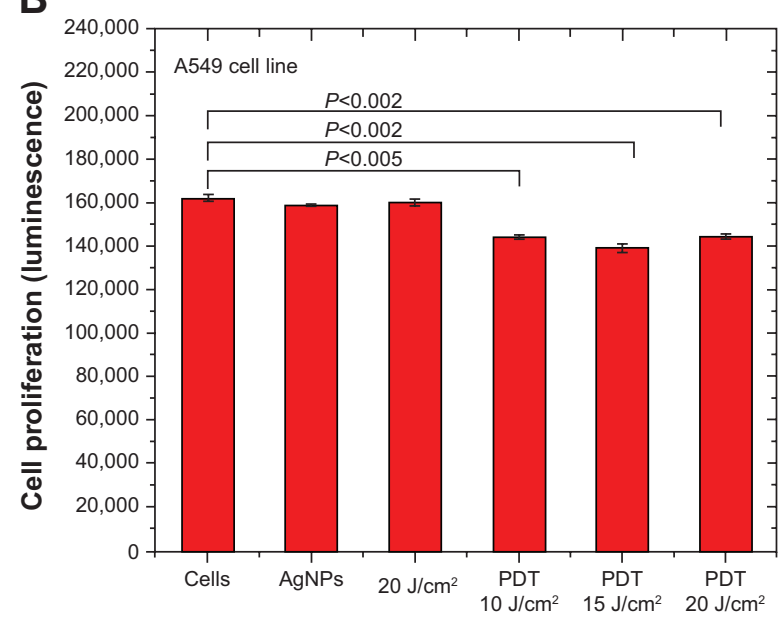

Figure 4 Cellular proliferation of both MCF-7 and A549 cancer cells after treatment.

Notes: (A) Neither $3.23 \mathrm{mg} / \mathrm{mL}$ of AgNPs (AgNPs) nor $20 \mathrm{~J} / \mathrm{cm}^{2}$ laser irradiation $\left(20 \mathrm{~J} / \mathrm{cm}^{2}\right)$ induced major changes in MCF-7 cell proliferation, but all PDT-treated cells showed significant decreased proliferation $(P<0.00 \mathrm{I})$ when compared to untreated cells (cells). (B) In the same way, neither $3.23 \mathrm{mg} / \mathrm{mL}$ of $\mathrm{AgNPs}(\mathrm{AgNPs})$ nor $20 \mathrm{~J} / \mathrm{cm}^{2}$ laser irradiation $\left(20 \mathrm{~J} / \mathrm{cm}^{2}\right)$ induced major changes in cell proliferation in A549 cells, but significant decreases were seen with PDT-treated cells with $10 \mathrm{~J} / \mathrm{cm}^{2}$ and $15 \mathrm{~J} / \mathrm{cm}^{2}(P<0.002)$ and $20 \mathrm{~J} / \mathrm{cm}^{2}(P<0.005)$.

Abbreviations: AgNPs, silver nanoparticles; PDT, photodynamic therapy. 

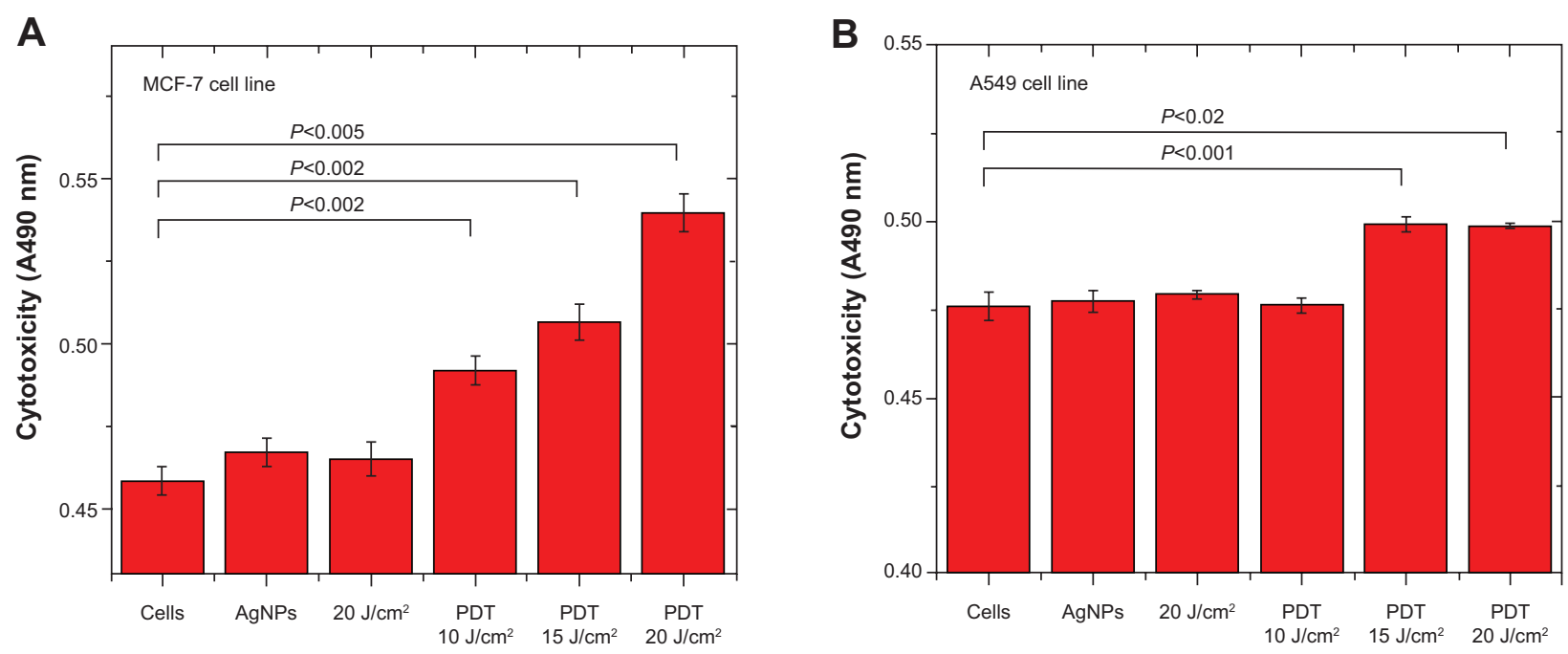

Figure 5 Cytotoxicity of MCF-7 breast and A549 lung cancer cells after treatment.

Notes: (A) Neither $3.23 \mathrm{mg} / \mathrm{mL}$ of AgNPs (AgNPs) nor $20 \mathrm{~J} / \mathrm{cm}^{2}$ laser irradiation $\left(20 \mathrm{~J} / \mathrm{cm}^{2}\right)$ induced major changes in cytotoxicity, but significant increase in LDH levels were seen with PDT-treated MCF-7 cells at $10 \mathrm{~J} / \mathrm{cm}^{2}$ and $15 \mathrm{~J} / \mathrm{cm}^{2}(P<0.002)$, as well as at $20 \mathrm{~J} / \mathrm{cm}^{2}(P<0.005)$ when compared to untreated cells (cells). (B) Similarly, neither $3.23 \mathrm{mg} / \mathrm{mL}$ of AgNPs (AgNPs), $20 \mathrm{~J} / \mathrm{cm}^{2}$ laser irradiation $\left(20 \mathrm{~J} / \mathrm{cm}^{2}\right)$, nor PDT at $10 \mathrm{~J} / \mathrm{cm}^{2}$ induced major changes in cytotoxicity, but significant increases in LDH levels were seen in PDT-treated A549 cells at I5 J/cm $\mathrm{cm}^{2}(P<0.00 \mathrm{I})$ and $20 \mathrm{~J} / \mathrm{cm}^{2}(P<0.02)$.

Abbreviations: AgNPs, silver nanoparticles; PDT, photodynamic therapy; LDH, lactate dehydrogenase.

cell lines populations; however, they were not significant. A study by Sriram et al ${ }^{43}$ illustrated that AgNPs can distinguish between malignant and normal cells, and they can induce antitumor activities by caspase-3 activation, which led to a restorative response and decreased tumor volume. Caspase is a family of cysteine proteases that are involved in cell death pathways. ${ }^{44,45}$ Another study showed that AgNPs induced cell death through caspase-3 activation and deoxyribonucleic acid (DNA) fragmentation, which are both apoptotic events. ${ }^{36}$ It is well established that the accumulation of reactive oxygen and/or nitrogen species induces and controls apoptosis. The ability of AgNPs to generate such species led to phosphatidylserine externalization, DNA and nuclear fragmentation, mitochondria dysfunction, and caspase activity in cancer cells. ${ }^{42,46-48}$ The results suggest that the mode of cell death induced coincides with that found during photodynamic therapy. Although cell death due to photothermal effects has been identified, ${ }^{49}$ the laser irradiation applied during this study does not support the induction of thermal effects. In a comparative study, it

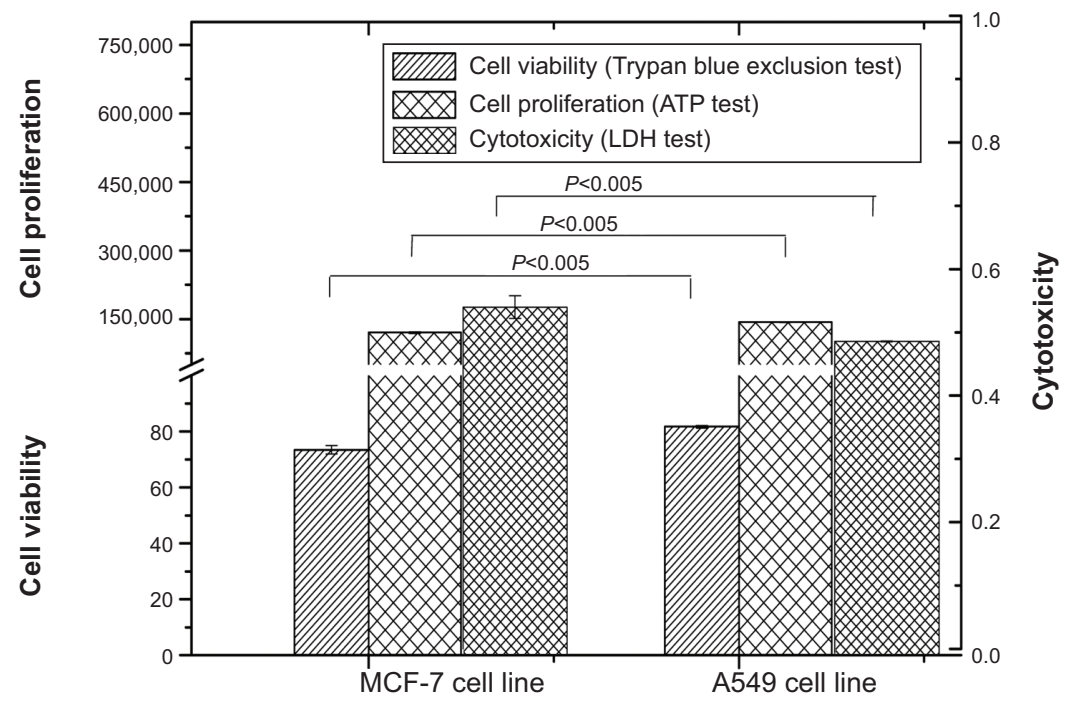

Figure 6 Comparison of cell viability (Trypan blue), proliferation (ATP), and cytotoxicity (LDH) of MCF-7 breast and A549 lung cancer cells after treatment using 3.23 mg/mL of AgNPs and $20 \mathrm{~J} / \mathrm{cm}^{2}$ laser irradiation.

Notes: Better survival rate (viability and proliferation; $P<0.005)$ and reduced cytodamage $(P<0.005)$ were seen in A549 cells when compared to MCF-7 cells. Abbreviations: ATP, adenosine triphosphate; LDH, lactate dehydrogenase; AgNPs, silver nanoparticles. 
Table 3 Percentages of cell populations after treatment of MCF-7 and A549 cells

\begin{tabular}{|c|c|c|c|c|}
\hline \multirow{2}{*}{$\begin{array}{l}\text { Experimental } \\
\text { groups }\end{array}$} & \multicolumn{4}{|c|}{ Cell populations (\%) } \\
\hline & Normal & $\begin{array}{l}\text { Early } \\
\text { apoptosis }\end{array}$ & $\begin{array}{l}\text { Late } \\
\text { apoptosis }\end{array}$ & Necrosis \\
\hline \multicolumn{5}{|l|}{ MCF-7 cells } \\
\hline Cells & 96 & 3 & 0 & 1 \\
\hline $\mathrm{AgNPs}$ & 94 & 4 & 2 & 0 \\
\hline $20 \mathrm{~J} / \mathrm{cm}^{2}$ & 86 & 9 & 3 & 2 \\
\hline PDT $10 \mathrm{~J} / \mathrm{cm}^{2}$ & 84 & 12 & 3 & 2 \\
\hline PDT $15 \mathrm{j} / \mathrm{cm}^{2}$ & $52 * * *$ & $39 * *$ & 8 & 1 \\
\hline PDT $20 \mathrm{~J} / \mathrm{cm}^{2}$ & $20 * * *$ & 43 & 6 & 1 \\
\hline \multicolumn{5}{|l|}{ A549 cells } \\
\hline Cells & 94 & 2 & 1 & 3 \\
\hline $\mathrm{AgNPs}$ & 93 & 2 & 3 & 2 \\
\hline $20 \mathrm{~J} / \mathrm{cm}^{2}$ & 95 & 3 & 2 & 0 \\
\hline PDT $10 \mathrm{~J} / \mathrm{cm}^{2}$ & 91 & 4 & 4 & 1 \\
\hline PDT $15 \mathrm{~J} / \mathrm{cm}^{2}$ & 89 & 6 & 4 & I \\
\hline PDT $20 \mathrm{~J} / \mathrm{cm}^{2}$ & $79 *$ & 10 & 9 & 2 \\
\hline
\end{tabular}

Notes: Neither cells treated with $3.23 \mathrm{mg} / \mathrm{mL}$ of AgNPs (AgNPs) nor laser irradiation $\left(20 \mathrm{~J} / \mathrm{cm}^{2}\right)$ induced significant changes in each population (normal, early apoptosis, late apoptosis, and necrosis) when compared to the corresponding populations of the untreated cells (cells). Significant changes in both normal and early apoptotic populations of MCF-7 cells treated with PDT at I5 or $20 \mathrm{~J} / \mathrm{cm}^{2}$, were seen and indicated as $* * P<0.002$ and $* * * P<0.001$. A549 cells treated with PDT at $20 \mathrm{~J} / \mathrm{cm}^{2}$ led to a significant decrease in the normal population and was indicated as $* P<0.005$ when compared to the corresponding untreated cells (cells).

Abbreviations: AgNPs, silver nanoparticles; PDT, photodynamic therapy.

was established that laser irradiation caused the generation of reactive oxygen species, which led to greater cancer cell destruction than did photothermal effects. ${ }^{50}$ In the irradiation therapeutic window using laser parameters, as was applied during this study, the effect was mostly athermic with limited heat transfer $\left(<0.65^{\circ} \mathrm{C}\right) .{ }^{51}$

\section{Conclusion}

The synthesized spherical shape of AgNPs with an average size of $27 \mathrm{~nm}$ was able to penetrate and localize in both MCF-7 and A549 cancer cells. This study showed that AgNPs displayed good photodynamic effects and induced increased cytotoxicity and decreased cell viability and proliferation. AgNP-mediated photodynamic treatment potentially generated $\mathrm{Ag}^{+}$cations that led to the induction of cell death through an apoptotic manner, and in both cell lines, with MCF-7 cells being more sensitive to the treatment. This study showed that AgNPs are potent effectors of cell death, but that the mechanisms underlying the increased cytodestruction found in MCF-7 cells when compared to A549 cells have to be further investigated in order to improve the effectiveness of this treatment.

\section{Acknowledgments}

This work was conducted at the Laser Research Centre at the University of Johannesburg and was supported by the African Laser Centre, National Research Foundation, and
University of Johannesburg of South Africa. We thank Professor Wolfgang Fritzsche, Nano Biophotonics Department, Institute of Photonic Technology (IPHT), Jena, Germany for the synthesis and supply of AgNPs. The National Laser Centre of South Africa is acknowledged for supplying and performing maintenance of the lasers.

\section{Disclosure}

The authors report no conflicts of interest in this work.

\section{References}

1. Cai W, Gao T, Hong H, Sun J. Applications of gold nanoparticles in cancer nanotechnology. Nanotechnol Sci Appl. 2008;1:17-32.

2. The Cancer Association of South Africa [homepage on the Internet] Overview of the latest national cancer register statistics. Johannesburg, South Africa: The Cancer Association of Africa; 2013. Available from: http://www.cansa.org.za/SOUTH-AFRICAN-CANCER-STATISTICS/. Accessed October 7, 2013.

3. Siegel R, Naishadham D, Jemal A. Cancer statistics, 2012. CA Cancer J Clin. 2012;62(1):10-29.

4. Al-Sohaily S, Biankin A, Leong R, Kohonen-Corish M, Warusavitarne J Molecular pathways in colorectal cancer. $J$ Gastroenterol Hepatol. 2012;27(9):1423-1431.

5. Fearon ER. Molecular genetics of colorectal cancer. Annu Rev Pathol. 2011;6:479-507.

6. Bertram L. Alzheimer's genetics in the GWAS era: a continuing story of 'replications and refutations'. Curr Neurol Neurosci Rep. 2011;11(3): 246-253.

7. Hanahan D, Weinberg RA. Hallmarks of cancer: the next generation. Cell. 2011;144(5):646-674.

8. American Cancer Society [webpage on the Internet]. Cancer facts and figures 2013. Atlanta, GA: American Cancer Society. Available from: http://www.cancer.org/acs/groups/content/@epidemiologysurveilance/documents/document/acspc-036845.pdf. Accessed October 6, 2013.

9. Kruger WM, Apffelstadt JP. Young breast cancer patients in the developing world: incidence, choice of surgical treatment and genetic factors South African Family Practice. 2007;49(9):18-24.

10. Moitra K, Lou H, Dean M. Multidrug efflux pumps and cancer stem cells: insights into multidrug resistance and therapeutic development Clin Pharmacol Ther. 2011;89(4):491-502.

11. Rathos MJ, Joshi K, Khanwalkar H, Manohar SM, Joshi KS. Molecular evidence for increased antitumor activity of gemcitabine in combination with a cyclin-dependent kinase inhibitor, $\mathrm{P} 276-00$ in pancreatic cancers. $J$ Transl Med. 2012;10:161.

12. Haller DG. New perspectives in the management of pancreas cancer. Semin Oncol. 2003;30(4 Suppl 11):3-10.

13. Cai $\mathrm{W}$, Chen $\mathrm{X}$. Nanoplatforms for targeted molecular imaging in living subjects. Small. 2007;3(11):1840-1854.

14. Boisseau P, Loubaton B. Nanomedicine, nanotechnology in medicine. Comptes Rendus Physique. 2011;12(7):620-636.

15. Walsh MD, Hanna SK, Sen J, et al. Pharmacokinetics and antitumor efficacy of XMT-1001, a novel, polymeric topoisomerase I inhibitor, in mice bearing HT-29 human colon carcinoma xenografts. Clin Cancer Res. 2012;18(9):2591-2602.

16. Caron WP, Song G, Kumar P, Rawal S, Zamboni WC. Interpatient pharmacokinetic and pharmacodynamic variability of carrier-mediated anticancer agents. Clin Pharmacol Ther. 2012;91(5):802-812.

17. Demling R, DeSanti L. The role of silver technology in wound healing: part 1: effects of silver on wound management. Wounds: a compendium of clinical research and practice. 2001;13(Suppl A):4-15.

18. Ovington L. The role of silver technology in wound healing: part 2. Why is nanocrystalline silver superior? Wounds. A compendium of clinical research and practice. 2001;13(Suppl B):5-10. 
19. Sant SB, Gill KS, Burrell RE. Novel duplex antimicrobial silver films deposited by magnetron sputtering. Philos Mag Lett. 2000; 80(4):249-256.

20. Shrestha A, Hamblin MR, Kishen A. Photoactivated rose bengal functionalized chitosan nanoparticles produce antibacterial/biofilm activity and stabilize dentin-collagen. Nanomedicine. 2014;10(3):491-501.

21. West JL, Halas NJ. Applications of nanotechnology to biotechnology commentary. Curr Opin Biotechnol. 2000;11(2):215-217.

22. Camerin M, Magaraggia M, Soncin M, et al. The in vivo efficacy of phthalocyanine-nanoparticle conjugates for the photodynamic therapy of amelanotic melanoma. Eur J Cancer. 2010;46(10):1910-1918.

23. Chen PC, Mwakwari SC, Oyelere AK. Gold nanoparticles: From nanomedicine to nanosensing. Nanotechnol Sci Appl. 2008;1:45-65.

24. Hussain SM, Javorina AK, Schrand AM, Duhart HM, Ali SF, Schlager JJ. The interaction of manganese nanoparticles with PC-12 cells induces dopamine depletion. Toxicol Sci. 2006;92(2):456-463.

25. El-Chaghaby GA, Ahmad AF. Biosynthesis of silver nanoparticles using Pistacia lentiscus leaves extract and investigation of their antimicrobial effect. Oriental Journal of Chemistry. 2011;27(3):929-936.

26. Naghsh N. Investigating the effect of silver nanoparticles on E.coli growth. QOM University of Medical Sciences Journal. 2012;6(2): $1-5$.

27. Liu CJ, Wang CH, Chien CC, et al. Enhanced $\mathrm{x}$-ray irradiation-induced cancer cell damage by gold nanoparticles treated by a new synthesis method of polyethylene glycol modification. Nanotechnology. 2008; 19(29):295104.

28. Kong T, Zeng J, Wang X, et al. Enhancement of radiation cytotoxicity in breast-cancer cells by localized attachment of gold nanoparticles. Small. 2008;4(9):1537-1543.

29. Knauer A, Csáki A, Möller F, Hühn C, Fritzsche W, Köhler JM. Microsegmented flow-through synthesis of silver nanoprisms with exact tunable optical properties. J Phys Chem C Nanomater Interfaces. 2012;116(16):9251-9258.

30. Kelly JM, Keegan G, Brennan-Fournet ME. Triangular silver nanoparticles: their preparation, functionalisation and properties. Acta Physica Polonica A. 2012;122:337-345.

31. Fotakis G, Timbrell JA. In vitro cytotoxicity assays: comparison of LDH, neutral red, MTT and protein assay in hepatoma cell lines following exposure to cadmium chloride. Toxicology Letters. 2006;160:171-177.

32. Zhou G, Wang W. Synthesis of silver nanoparticles and their antiproliferation against human lung cancer cells in vitro. Oriental Journal of Chemistry. 2012;28(2):651-655.

33. Salem HF, Eid KAM, Sharaf MA. Formulation and evaluation of silver nanoparticles as antibacterial and antifungal agents with a minimal cytotoxic effect. International Journal of Drug Delivery. 2011;3(2): 293-304.

34. Tynga IM, Houreld NN, Abrahamse H. The primary subcellular localization of Zinc phthalocyanine and its cellular impact on viability, proliferation and structure of breast cancer cells (MCF-7). J Photochem Photobiol B. 2013;120:171-176.

35. Manoto SL, Abrahamse H. Effect of a newly synthesized Zn sulfophthalocyanine derivative on cell morphology, viability, proliferation, and cytotoxicity in a human lung cancer cell line (A549). Lasers Med Sci. 2011;26(4):523-530.

International Journal of Nanomedicine

\section{Publish your work in this journal}

The International Journal of Nanomedicine is an international, peerreviewed journal focusing on the application of nanotechnology in diagnostics, therapeutics, and drug delivery systems throughout the biomedical field. This journal is indexed on PubMed Central, MedLine, CAS, SciSearch ${ }^{\circledR}$, Current Contents ${ }^{\circledR} /$ Clinical Medicine,
36. Satyavani K, Gurudeeban S, Ramanathan T, Balasubramanian T. Biomedical potential of silver nanoparticles synthesized from calli cells of Citrullus colocynthis (L.) Schrad. J Nanobiotechnology. 2011;9:43.

37. Yang J, Wang $\mathrm{H}$, Wang $\mathrm{Z}$, et al. Interaction between antitumor drug and silver nanoparticles: combined fluorescence and surface enhanced Raman scattering study. Chin Opt Lett. 2009;7(10):894-897.

38. Xu R, Ma J, Sun X, et al. Agnanoparticles sensitize IR-induced killing of cancer cells. Cell Res. 2009;19(8):1031-1034.

39. AshaRani PV, Low KahMun G, Hande MP, Valiyaveettil S. Cytotoxicity and genotoxicity of silver nanoparticles in human cells. ACS Nano. 2009;3(2):279-290.

40. Kazi A, Daniel KG, Smith DM, Kumar NB, Dou QP. Inhibition of the proteasome activity, a novel mechanism associated with the tumor cell apoptosis-inducing ability of genistein. Biochemical Pharmacology. 2003;66(6):965-976.

41. Gordan JD, Thompson CB, Simon MC. HIF AND C-MYC: sibling rivals for control of cancer cell metabolism and proliferation. Cancer Cell. 2007;12(2):108-113.

42. Franco-Molina MA, Mendoza-Gamboa E, Sierra-Rivera CA, et al. Antitumor activity of colloidal silver on MCF-7 human breast cancer cells. J Exp Clin Cancer Res. 2010;29:148.

43. Sriram MI, Kanth SB, Kalishwaralal K, Gurunathan S. Antitumor activity of silver nanoparticles in Dalton's lymphoma ascites tumor model. Int J Nanomedicine. 2010;5:753-762.

44. Tynga IM, Abrahamse H. Caspase- 8 properties, functions and regulation during photodynamic therapy. In: Urbano KV, editor. Advances in Genetics Research. New York, NY: Nova Sciences Publishers; 2012:107-119.

45. Alnemri ES, Livingston DJ, Nicholson DW, et al. Human ICE/ CED-3 protease nomenclature. Cell. 1996;87(2):171.

46. Rosarin FS, Arulmozhi V, Nagarajan S, Mirunalini S. Antiproliferative effect of silver nanoparticles synthesized using amla on Hep2 cell line. Asian Pac J Trop Med. 2013;6(1):1-10.

47. Sur I, Altunbek M, Kahraman M, Culha M. The influence of the surface chemistry of silver nanoparticles on cell death. Nanotechnology. 2012;23(37):375102.

48. Hwang IS, Lee J, Hwang JH, Kim KJ, Lee DG. Silver nanoparticles induce apoptotic cell death in Candida albicans through the increase of hydroxyl radicals. FEBS J. 2012;279(7):1327-1338.

49. Lal S, Clare SE, Halas NJ. Nanoshell-enabled photothermal cancer therapy: impending clinical impact. ACC. Chem. Res. 2008;41(12):1842-1851.

50. Murakami T, Nakatsuji H, Inada M, et al. Photodynamic and photothermal effects of semiconducting and metallic-enriched single-walled carbon nanotubes. J Am Chem Soc. 2012;134(43):17862-17865.

51. Matić M, Lazetić B, Poljacki M, Duran V, Ivkov-Simić M. [Low level laser irradiation and its effect on repair processes in the skin]. Med Pregl. 2003;56(3-4):137-141. Croatian.

Journal Citation Reports/Science Edition, EMBase, Scopus and the Elsevier Bibliographic databases. The manuscript management system is completely online and includes a very quick and fair peer-review system, which is all easy to use. Visit http://www.dovepress.com/ testimonials.php to read real quotes from published authors. 